\title{
Shelf-life Estimation of Frankfurter Sausage Containing Dietary Fiber from Rice Bran Using Predictive Modeling
}

\author{
Chan Heo, Hyoun Wook Kim, Yun-Sang Choi, Cheon-Jei Kim, and Hyun-Dong Paik* \\ Division of Animal Life Science, Konkuk University, Seoul 143-701, Korea \\ 예측미생물을 이용한 미강식이섬유 함유 프랑크푸르터 소시지의 유통기한 설정 \\ 허찬 · 김현욱 · 최윤상 · 김천제・백현동* \\ 건국대학교 동물생명과학부
}

\begin{abstract}
Predictive modeling was applied to study the growth of microorganisms related to spoilage in frankfurter sausage containing various levels of dietary fiber $(0,1,2$, and $3 \%)$ from rice bran and to estimate its shelf-life. Using the Baranyi model, total viable cells, anaerobic and psychrotrophic bacteria were measured during 35 days of cold storage $\left(<4 \pm 1^{\circ} \mathrm{C}\right)$. The lag times (LT) demonstrated by control and treatment groups were $6.28,623,6.24$, and 6.25 days, respectively. The growth rate of total viable cells in each group were $0.95,0.91,0.92$, and 0.91 ( $\log$ CFU/g/day), respectively. The anaerobic and psychrotrophic bacteria had lower initial $\left(\mathrm{y}_{0}\right)$ and maximal bacterial counts $\left(y_{\max }\right)$ than total viable cells. Also, the anaerobic and psychrotrophic bacteria possessed lower growth rate and longer lag time than total viable cells. The estimated shelf-life of frankfurter containing rice bran fiber by the growth rate of total viable cells was 7.8, 7.9, 7.9, and 7.7 days, respectively. There were no significant differences in shelf-life as a function of fiber content. In other words, the addition of dietary fiber in sausage did not show the critically hazardous results in growth of microorganism. The 12 predictive models were then characterized by high $R^{2}$, and small RMSE. Furthermore, $B_{f}$ and $A_{f}$ values showed a very close relationship between the predictive and observed data.
\end{abstract}

Key words : frankfurter sausage, predictive modeling, Baranyi function, dietary fiber, shelf-life

\section{Introduction}

Changes in eating habits and life styles have contributed significantly to the increased numbers of individuals who are overweight or obese in modern society (Aranceta, 2003). There has also been a significant increase in the number of fast food restaurants and amount of inexpensive food at supermarkets, possibly coinciding with certain life-style change, such as the increase in alcohol consumption, and sedentary habits (Martin et al., 2008). However, the demands of high-quality and distribution of well-fitted nutrition on meat products are still increasing. Therefore, people and society are concerned with the obesity, high blood pressure, cancer, and heart disease seri-

*Corresponding author : Hyun-Dong Paik, Division of Animal Life Science, Konkuk University, Seoul 143-701, Korea. Tel: 82-2-2049-6011, Fax: 82-2-455-3082, E-mail: hdpaik@konkuk. ac.kr ously (Chin et al., 2005).

In recent years, researchers have been interested in understanding the impact of dietary fiber in solving these emerging health problems (Abdul-Hamid and Luan, 2000). Intake of dietary fiber has positive effects against chronic diseases, such as cardiovascular diseases, diverticulosis, diabetes and colon cancer (Cara et al., 1992; Wrick et al., 1983). Dietary fiber also affects the functional properties of food (Elleuch et al., 2008). Dietary fiber can be added to foods (meat, bakery products) to modify textural properties, avoid syneresis, and stabilize high fat food and emulsions (Abdul-Hamid and Luan, 2000; Choi et al., 2007; Wang et al., 2002).

The microbiological safety of food should be considered as well as its nutrition and functionality. However, the scientific vulnerability of shelf-life estimation by the companies themselves was indicated by the government. Therefore, KFDA (Korean Food and Drug Administration) has established new rule(s) for estimating the shelf- 
life of food products to present the scientific proof and improve the reliability of the safe food (KFDA, Notification No. 2007-66). Thus, the food industry should present scientific evidence such as physical, sensory, and microbiological properties of newly developed products to verify shelf-life.

Predictive modeling has been used to estimate the growth of bacteria related to spoilage of foods in order to calculate the shelf-life or specific pathogenic bacteria in food for quantitative risk assessments. Specific spoilage organisms are selected and used as test organisms: i.e. Brochothrix thermosphacta (Baranyi et al., 1995). For example, predictions of Listeria monocytogenes growth in sesame leaves were based on environment factors (Park et al., 2007) and the probable intake time of readyto-eat Kimbap in market was calculated by using the Food MicroModel based on Gompertz model (Lee et al., 2004).

The purpose of this study was to apply predictive modeling to study the growth of microorganisms related to spoilage of frankfurter sausage containing various levels of dietary fiber (rice bran at $0,1,2$, or $3 \%$ ) and estimate its shelf-life more reliably.

\section{Materials and Methods}

\section{Extraction of dietary fiber from rice bran}

Dietary fiber from rice bran was extracted by the modified AOAC enzymatic-gravimetric method (AOAC, 1995). Rice bran of a Japonica rice cultivar (Oriza sativa L.) was purchased from local market in Seoul. This rice bran was ground in a mill and passed through a 25 mesh sieve. The ground rice bran roasted at a temperature of about $105^{\circ} \mathrm{C}$, and then defatted with hexane ( $n$-hexane 95\%) using a shaker (BS-11, Lab Companion, Korea) overnight. The defatted rice bran was gelatinized with $0.6 \%$ termamyl (LS, Novozymes, Denmark) at $95^{\circ} \mathrm{C}$ for 1 $\mathrm{hr}$ to remove starches, and then filtered. The residue was then washed three times using four volumes of heated water $\left(100^{\circ} \mathrm{C}\right)$ and was allowed to equilibrate to room temperature $\left(20^{\circ} \mathrm{C}, 6 \mathrm{hr}\right)$. The residue was then washed with $99.9 \%$ ethanol (preheated to $60^{\circ} \mathrm{C}$ ), and then filtered. The residue was then dried overnight in an air oven $\left(55^{\circ} \mathrm{C}\right)$ and then cooled. The dietary fiber extracted from rice bran was placed in polyethylene bags and vacuum packaged using a vacuum packaging system (FJ-500XL, Fujee Tech, Seoul, Korea). The extracted fiber was then stored at $4^{\circ} \mathrm{C}$ until required for product manufacture.

\section{Preparation of frankfurter sausage}

Pork ham and pork back fat were purchased from a local market in Seoul. All subcutaneous and intramuscular fat and connective tissue were removed from meat. Lean pork and fat were ground through an $8 \mathrm{~mm}$ plate. Each batch of samples consisted of four meat batters which differed in their composition by adding rice bran extracts $(0,1,2$, and $3 \%)$. Four different types of frankfurter were formulated with sugar (CJ Co., Seoul, Korea), MSG (CJ Co., Seoul, Korea), garlic powder (Dongbang Food Master Co., Seoul, Korea), onion powder (Dongbang Food Master Co., Seoul, Korea) and sodium nitrite (Daesan Chemicals Co., Cheonan, Korea) (Table 1). Raw meat was homogenized and ground for $1 \mathrm{~min}$ in a silent cutter (Cutter Nr-963009, Scharfen, Germany). 1.5\% $\mathrm{NaCl}$ (CJ Co., Seoul, Korea) and $0.2 \%$ sodium triployphosphate (Samchum Purechemical Co., Ltd., Seoul, Korea) previously dissolved in water and chilled $\left(2^{\circ} \mathrm{C}\right)$ was then added to the meat mixture and mixed for $1 \mathrm{~min}$. After mixing, the rice bran extract $(0,1,2$, or $3 \%)$ was added and batters were homogenized for $1 \mathrm{~min}$. The emulsion was maintained temperatures $<10^{\circ} \mathrm{C}$ and a temperature probe (Kane-May, KM330, Germany) was used to monitor the temperature during this process. After emulsifying, meat batter was stuffed into collagen casing (\#240, NIPPI Inc., Tokyo, Japan; approximate diameter of $25 \mathrm{~mm}$ ) using a stuffer (Stuffer IS-8, Sirman, Italy). The frankfurters were then heated at $75^{\circ} \mathrm{C}$ for $30 \mathrm{~min}$ in a water bath (model 10-101, Dae Han Co., Korea). Ten kg samples of each frankfurter were prepared using this method. Microbiological analysis was performed over a period of 35 days of storage at $4 \pm 1^{\circ} \mathrm{C}$.

Table 1. The formulation of frankfurter sausage containing dietary fiber

\begin{tabular}{clcccc}
\hline \multirow{2}{*}{ Ingredients } & \multicolumn{4}{c}{ Formulation (\%, batch) } \\
\cline { 3 - 6 } & \multicolumn{1}{c}{$\mathrm{C}^{1)}$} & $\mathrm{T}^{2)}$ & $\mathrm{T}^{3)}$ & $\mathrm{T}^{4)}$ \\
\hline \multirow{2}{*}{ Main } & Pork ham & 50 & 50 & 50 & 50 \\
material & Pork fat & 25 & 25 & 25 & 25 \\
& Water & 25 & 25 & 25 & 25 \\
\hline \multirow{2}{*}{ Additive } & Dietary fiber & 0 & 1.0 & 2.0 & 3.0 \\
& Salt & 1.5 & 1.5 & 1.5 & 1.5 \\
& Sodium nitrite & 0.01 & 0.01 & 0.01 & 0.01 \\
& Phosphate & 0.2 & 0.2 & 0.2 & 0.2 \\
& MSG ${ }^{5)}$ & 0.08 & 0.08 & 0.08 & 0.08 \\
& Onion powder & 0.05 & 0.05 & 0.05 & 0.05 \\
& Garlic powder & 0.05 & 0.05 & 0.05 & 0.05 \\
Sugar & 0.5 & 0.5 & 0.5 & 0.5 \\
\hline
\end{tabular}

${ }^{1)}$ Control, ${ }^{2)}$ frankfurter with $1 \%$ fiber added, ${ }^{3)}$ frankfurter with $2 \%$ fiber added, ${ }^{4)}$ frankfurter with $3 \%$ fiber added, ${ }^{5)}$ Monosodium Lglutamate. 


\section{Microbiological analysis of frankfurter sausages}

For bacterial counts in frankfurter sausage, bacteriological analytical manual was used (BAM, 2003). To determine the bacterial counts for each sample, $10 \mathrm{~g}$ of sausage was aseptically transferred into a sterile stomacher bag and $100 \mathrm{~mL}$ of sterile $0.1 \%$ peptone water (Difco, USA) was added. The sample was then homogenized in a stomacher (Masticator-Paddle-Blender, IUL Instrument, Spain) for $2 \mathrm{~min}$ at normal speed and aliquots were plated out directly as 10 -fold dilutions in $0.1 \%$ peptone water. After serially diluting each sample in sterile peptone water, $0.1 \mathrm{~mL}$ portions of the samples were separately plated onto each of plates. Total viable cells and anaerobic bacterial counts were enumerated by incubation on plate count agar (PCA; Difco, Sparks, MD, USA) at $35^{\circ} \mathrm{C}$ for $48 \mathrm{hr}$ and anaerobic bacteria was determined by spread-plating on PCA using AnaeroGen (Oxoid, Hampshire, UK) and BBL anaerobic jar (Difco, USA) at $35^{\circ} \mathrm{C}$ for $48 \mathrm{hr}$. Psychrotrophic bacteria were incubated at $10^{\circ} \mathrm{C}$ for 7 days on PCA. After incubation such plates, which contained 30 to 300 colonies on a plate, were chosen for counting. All analyses were performed three times and counts were expressed as colony-forming units per gram (CFU/g).

\section{Predictive models of the bacterial growth in frank- furter sausage}

The growth data were analyzed with widely used Baranyi model (Baranyi et al., 1995; Baranyi et al., 1996). Baranyi model has been reparameterized in terms of more familiar quantities. The reparameterized model is described by form (1), (2), and (3).

$$
\begin{aligned}
& y(t)=y_{0}+\frac{y_{1}}{\ln (10)}-\frac{y_{2}}{\ln (10)} \\
& y_{1}=\mu \cdot t+\ln \left[e^{-\mu \cdot t}-e^{-\mu\left(t+t_{\text {lag }}\right)}+e^{-e \cdot t_{\text {lag }}}\right] \\
& y_{2}=\ln \left[1+10^{\left(y_{0}-y_{\max }\right)} \cdot\left(e^{\mu\left(t-t_{\text {lag }}\right)}-e^{-\mu \cdot t_{\text {lag }}}\right)\right]
\end{aligned}
$$

Where $y(t)$ is the bacterial count in $\log \mathrm{CFU} / \mathrm{g}$ at time $t$; $y_{0}$ is the initial bacteria count in Log CFU/g at time 0; $y_{\max }$ is the maximum bacteria count in $\mathrm{Log} \mathrm{CFU} / \mathrm{g} ; t_{\mathrm{lag}}$ means lag time (LT); $\mu_{\max }$ is the maximum specific growth rate, Log CFU/g/day. The average parameters of $y_{0}, y_{\max }, \mathrm{LT}, \mu_{\max }$ in this study were determined by using the MicroFit version 1.0 (developed by the Institute of Food Research, Norwich, UK).

\section{Evaluation of predictive models}

The indices used for comparisons of predicted and observed data were: the determination coefficient $R^{2}$, modified bias factors, accuracy factors $\left(B_{f}, A_{f}\right.$, respectively), and root mean square error (RMSE) (Baranyi et al., 1996; Ross et al., 2000).

$$
\begin{aligned}
& B_{f}=10^{\left(\frac{\sum \log (\text { pred/obs })}{n}\right)} \\
& A_{f}=10^{\left(\frac{\sum \mid \log (\text { pred/obs })}{n}\right)} \\
& \text { RMSE }=\sqrt{\frac{\sum(\text { obs }- \text { pred })^{2}}{n}}
\end{aligned}
$$

Where obs means observed value; pred means predicted value; $n$ is the number of observations. Perfect agreement between predictions and observations leads to bias and accuracy equal to 1.0. If $A_{f}$ value higher than 1 , the $A_{f}$ indicates that predicted values are larger than observed values. RMSE is effectively the average difference between the model and the data points. It provides a more intuitive measure of how well the model fits the data. It has the same units as the data (typically Log CFU/ g) (Equation (6)).

\section{Estimation of shelf-life}

The shelf-life of frankfurter sausage was calculated by the enumeration of total viable cells. $4 \mathrm{Log} \mathrm{CFU} / \mathrm{g}$ is the critical level of total viable cells allowed in cooked meat products as specified by the Korean Food Standards Codex (Korean Food and Drug Administration, 2008). Thus the time to reach the limit of $4 \mathrm{Log}$ CFU/g, which was calculated from primary models, was denoted as the predicted shelf-life. And the estimated shelf-life (Equation (7)) is calculated by taking the product of the predicted shelf-life times the safety factor (Koo et al., 2007).

$$
\begin{aligned}
& \text { Estimated shelf-life } \\
& =\text { Predicted shelf-life } \times \text { Safety factor }(1 / 1.5)
\end{aligned}
$$

Korean Health Industry Development Institute (KHIDI) denoted that the safety factor was the probable time, being able to maintain the quality of target products and the commercial shelf-life (mentioned as the estimated shelf-life) of products should reflect safety factor (KHIDI, 2008). The safety factor can be changeable depending on purpose and type of foods. There is not enough data about safety factor now. Therefore we used the value of safety factor (1/1.5) which was recommended on ready-to-eat food (Koo et al., 2007).

\section{Statistical analysis}

An analysis of variance (ANOVA) was performed on 
all the variables measured using the general linear model (GLM) procedure of the SAS program (Statistics Analytical System, USA, 1999). The Duncan's multiple range tests was used to determine differences between treatment means.

\section{Results and Discussion}

\section{Application of predictive models on bacterial growth in frankfurter sausage}

On the basis of the observed data, predictive models were described by the Baranyi model. Fig. 1-3 shows total viable cells, anaerobic, and psychro- trophic bacterial predictive models in frankfurter sausage containing different dietary fiber levels, respectively. Table 2 shows the estimated growth parameters, $y_{0}, y_{\max }, \mu_{\max }$, and LT. The numbers of heat-stable bacteria were below detectable levels and coliforms were not detected in frankfurter samples (data not shown). Fig. 1 (A)-(D) show predictive models and experimental data points $(n=8)$ of total viable cells during 35 days of storage. Control and treatments for total viable cells had lag times of $6.28,623,6.24$, and 6.25 days, respectively. After this lag time, bacterial counts increased between 7 to 21 days of storage, reach- ing a maximal population $\left(y_{\max }\right)$ from 7.88 to $8.59 \mathrm{Log}$ CFU/g. After 35 days of storage, the counts of total viable cells maintained the constant levels of bacterial counts. Lag time values were not significantly different $(p>0.05)$. The growth rate of total viable cells showed 0.95, 0.91, 0.92, and 0.91 Log CFU/g/day, respectively. There were no significant differences in growth rates between control and treatment groups (T1, T2, and T3; $p>0.05$ ).

Anaerobic bacteria had lower initial $\left(y_{0}\right)$ and maximal bacterial counts $\left(y_{\max }\right)$ compared to counts of total viable cells. Also growth rate values, $0.65,0.68,0.67$, and 0.70 $\mathrm{Log}$ CFU/g/day were lower than the growth rate values of total viable cells (Table 2). There were no significant differences in growth rates among control, T1, T2, and T3 groups $(p>0.05)$. However, lag times in anaerobic bacteria samples were longer than in total viable cells (i.e. 9.63, 9.10, 7.70, and 9.18 (days), respectively).

Fig. 3 (A)-(D) describe the predictive models of psychrotrophic bacteria in frankfurter samples. Psychrotrophic bacteria growth curves showed that control, T1, T2, and T3 were similar to total viable cells and anaerobic bacterial counts. The values of initial and maximum counts of control, T1, T2, and T3 groups showed no sig-
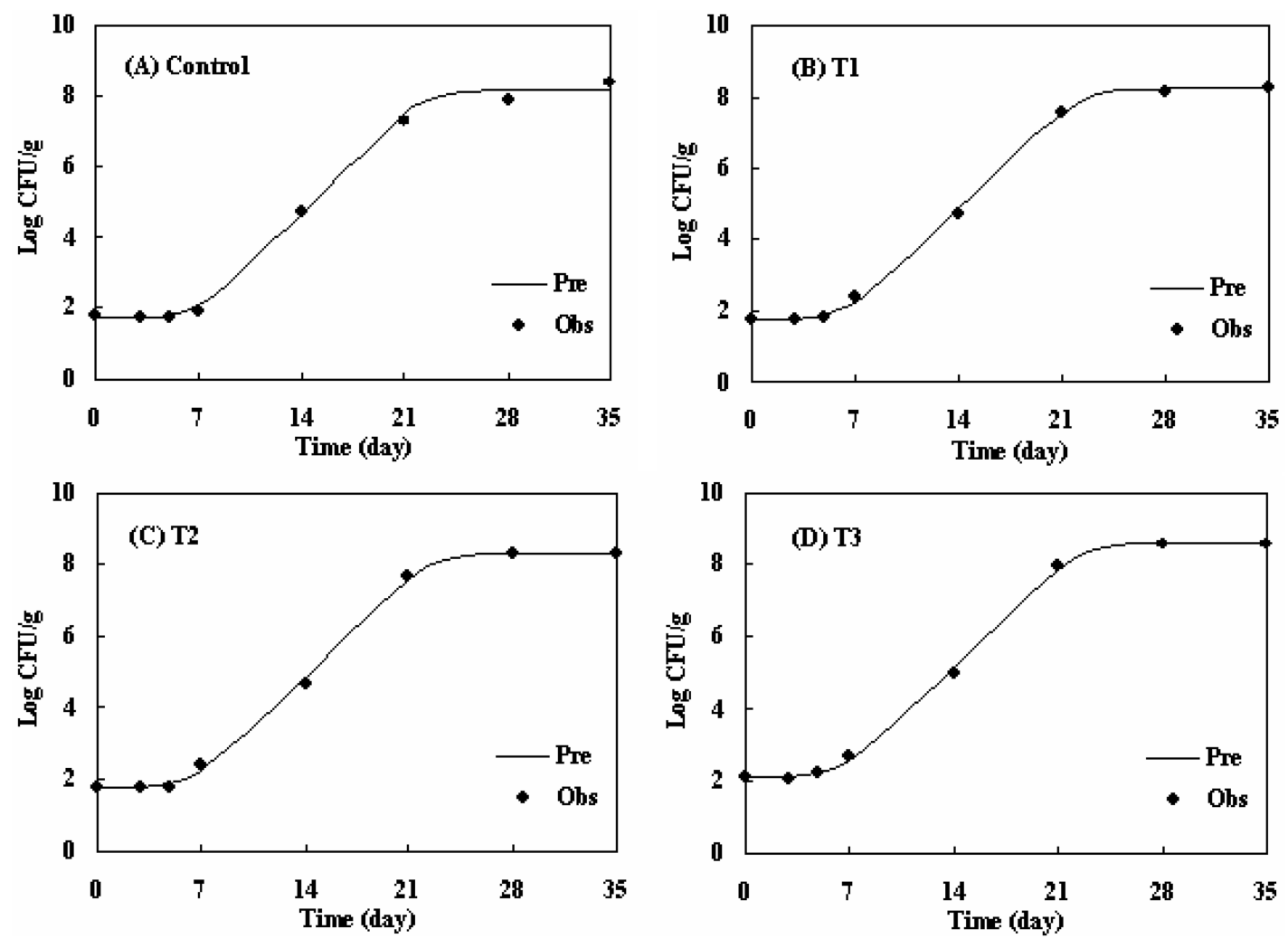

Fig. 1. Predictive models of total viable cells generated by the Baranyi model in frankfurter sausage containing dietary fiber during 35 days of storage at $4 \pm 1^{\circ} \mathrm{C}(-$, predicted data; $\odot$, observed data). 

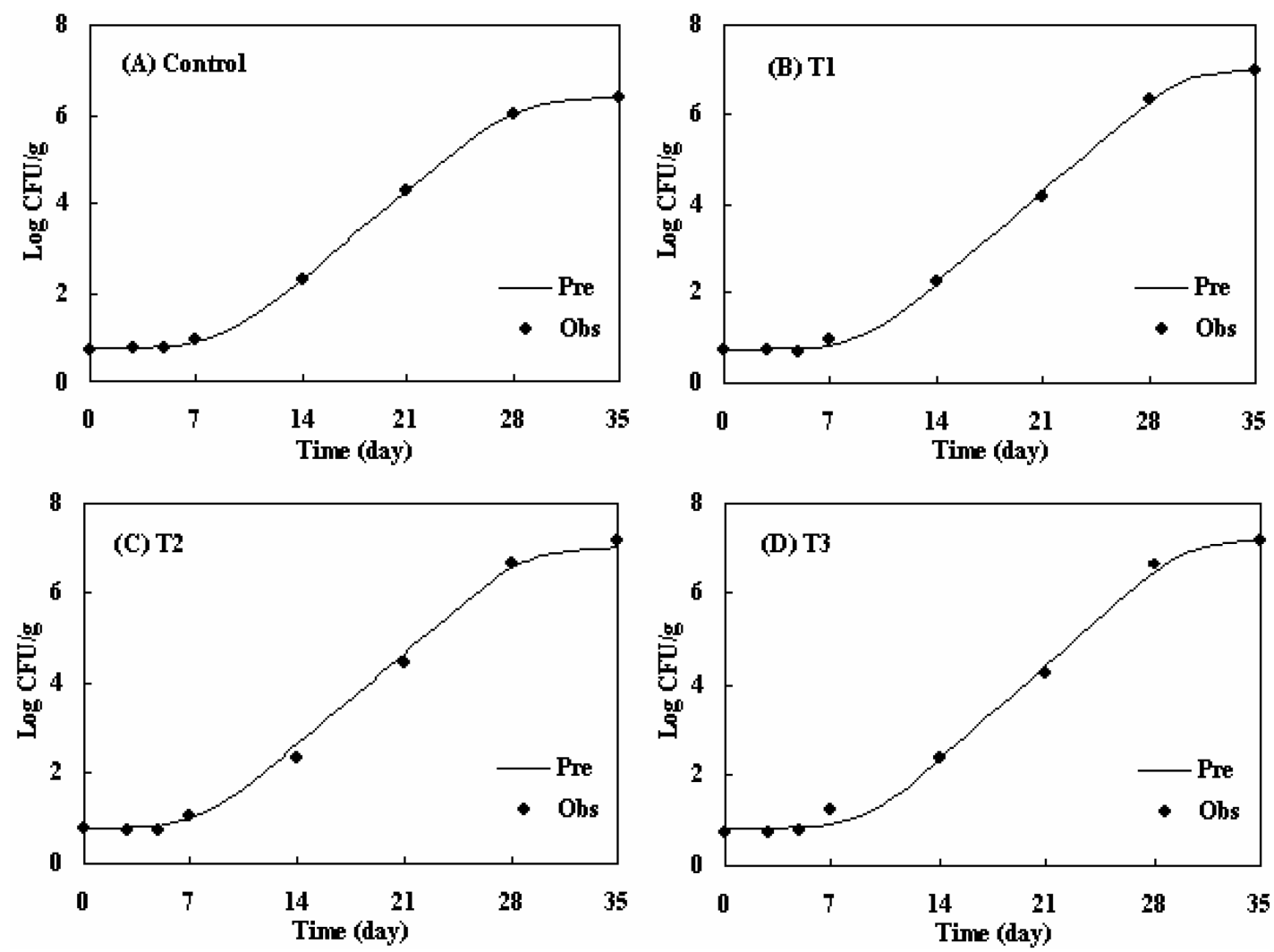

Fig. 2. Predictive models of anaerobic bacteria generated by the Baranyi model in frankfurter sausage containing dietary fiber during 35 days of storage at $4 \pm 1^{\circ} \mathrm{C}$ (一, predicted data; $\odot$, observed data).
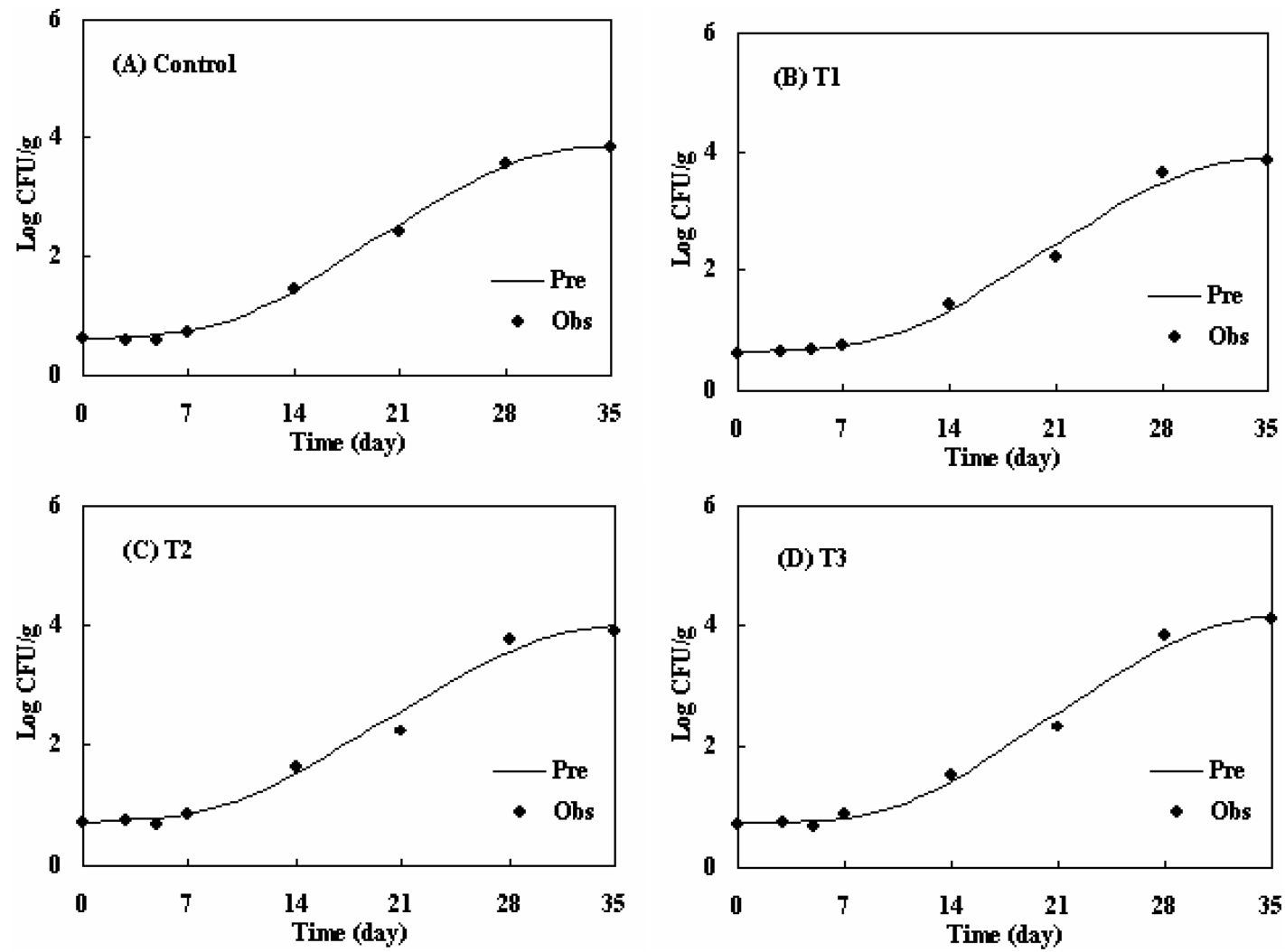

Fig. 3. Predictive models of psychrotrophic bacteria generated by the Baranyi model in frankfurter sausage containing dietary fiber during 35 days of storage at $4 \pm 1^{\circ} \mathrm{C}(-$, predicted data; 
Table 2. Growth parameters of microorganisms as predicted by the Baranyi model in frankfurter sausage containing dietary fiber

\begin{tabular}{|c|c|c|c|c|c|}
\hline \multirow{2}{*}{ Microorganism } & \multirow{2}{*}{ Type } & \multicolumn{4}{|c|}{ 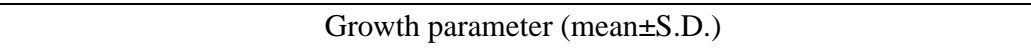 } \\
\hline & & $\mathrm{y}_{0}^{5)}$ & $y_{\max }^{6)}$ & $\mu_{\max }{ }^{7)}$ & $\mathrm{LT}^{8)}$ \\
\hline \multirow{4}{*}{ Total viable cells } & $\mathrm{C}^{1)}$ & $1.76 \pm 0.04^{\mathrm{b}}$ & $8.38 \pm 0.05^{\mathrm{b}}$ & $0.95 \pm 0.02^{\mathrm{a}}$ & $6.28 \pm 0.28^{\mathrm{a}}$ \\
\hline & $\mathrm{T} 1^{2)}$ & $1.78 \pm 0.08^{\mathrm{b}}$ & $8.25 \pm 0.08^{\mathrm{b}}$ & $0.91 \pm 0.04^{\mathrm{a}}$ & $6.23 \pm 0.50^{\mathrm{a}}$ \\
\hline & $\mathrm{T} 2^{3)}$ & $1.76 \pm 0.08^{b}$ & $8.28 \pm 0.08^{b}$ & $0.92 \pm 0.04^{\mathrm{a}}$ & $6.24 \pm 0.52^{\mathrm{a}}$ \\
\hline & $\mathrm{T} 3^{4)}$ & $2.08 \pm 0.07^{\mathrm{a}}$ & $8.59 \pm 0.08^{\mathrm{a}}$ & $0.91 \pm 0.04^{\mathrm{a}}$ & $6.25 \pm 0.48^{\mathrm{a}}$ \\
\hline \multirow{4}{*}{ Anaerobic bacteria } & $\mathrm{C}$ & $0.77 \pm 0.02^{\mathrm{a}}$ & $6.39 \pm 0.04^{\mathrm{b}}$ & $0.65 \pm 0.01^{\mathrm{a}}$ & $8.63 \pm 0.27^{\mathrm{ab}}$ \\
\hline & $\mathrm{T} 1$ & $0.74 \pm 0.06^{\mathrm{a}}$ & $7.02 \pm 0.01^{\mathrm{a}}$ & $0.68 \pm 0.03^{\mathrm{a}}$ & $9.10 \pm 0.54^{\mathrm{a}}$ \\
\hline & $\mathrm{T} 2$ & $0.76 \pm 0.07^{\mathrm{a}}$ & $7.04 \pm 0.12^{\mathrm{a}}$ & $0.67 \pm 0.03^{\mathrm{a}}$ & $7.70 \pm 0.71^{\mathrm{b}}$ \\
\hline & $\mathrm{T} 3$ & $0.82 \pm 0.12^{\mathrm{a}}$ & $7.2 \pm 0.23^{\mathrm{a}}$ & $0.70 \pm 0.06^{\mathrm{a}}$ & $9.18 \pm 1.16^{\mathrm{a}}$ \\
\hline \multirow{4}{*}{$\begin{array}{l}\text { Psychrotrophic } \\
\text { bacteria }\end{array}$} & $\mathrm{C}$ & $0.61 \pm 0.03^{\mathrm{a}}$ & $3.90 \pm 0.07^{\mathrm{a}}$ & $0.40 \pm 0.02^{\mathrm{a}}$ & $10.01 \pm 0.64^{\mathrm{a}}$ \\
\hline & $\mathrm{T} 1$ & $0.64 \pm 0.09^{\mathrm{a}}$ & $3.95 \pm 0.18^{\mathrm{a}}$ & $0.40 \pm 0.05^{\mathrm{a}}$ & $10.73 \pm 1.62^{\mathrm{a}}$ \\
\hline & $\mathrm{T} 2$ & $0.71 \pm 0.13^{\mathrm{a}}$ & $4.04 \pm 0.28^{\mathrm{a}}$ & $0.38 \pm 0.07^{\mathrm{a}}$ & $9.90 \pm 2.48^{\mathrm{a}}$ \\
\hline & $\mathrm{T} 3$ & $0.72 \pm 0.10^{\mathrm{a}}$ & $4.22 \pm 0.22^{\mathrm{a}}$ & $0.41 \pm 0.06^{\mathrm{a}}$ & $10.81 \pm 1.74^{\mathrm{a}}$ \\
\hline
\end{tabular}

${ }^{1)}$ Control, ${ }^{2)}$ frankfurter with $1 \%$ fiber added, ${ }^{3)}$ frankfurter with $2 \%$ fiber added, ${ }^{4)}$ frankfurter with $3 \%$ fiber added, ${ }^{5)}$ predictive initial cell count (Log CFU/g), ${ }^{6}$ predictive maximum cell count (Log CFU/g), ${ }^{7)}$ maximum specific growth rate (Log CFU/g/day), ${ }^{8)}$ lag time (days).

nificant differences $(p>0.05)$, and growth rates were lower than for total viable cells and anaerobic bacteria. The growth rate values were $0.40,0.40,0.38$ and 0.41 ( $\log \mathrm{CFU} / \mathrm{g} /$ day). The values were not significantly different $(p>0.05)$. Until now, usually the research has been studied about the effect of dietary fiber on food texture. Thus there are not enough literatures to compare and estimate the effect of dietary fiber on growth of microorganism in meat products. These results indicate that the contents of dietary fiber did not influence the growth rate and lag time. In other words, the addition in the range of 1,2 , and $3 \%$ of dietary fiber in sausage did not show the critically hazardous results, $y_{\max }, \mu_{\max }$ and LT, comparing with control.

\section{Evaluation of predictive models}

Traditionally, the source of foods to influence the growth of spoilage or pathogenic bacteria has been determined by inoculating with interested bacteria. However, the gap between the predicted data and the observed data still exists. Because the predicted data made under the aqueous phase such as broth, it showed usually faster growth than the observed data made under structured phase like sausages or meat (Koutosoumanis and Nychas, 2000; Wilson et al., 2002). To overcome this problem, we used other method that is using data obtained from experiments conducted on natural products. Therefore, these models may show more accurately the growth of bacteria in frankfurter containing dietary fiber. To evaluate the predictive models, the indices used for comparisons of predicted and observed data were $B_{f}, A_{f}, \mathrm{RMSE}$, and $R^{2}$.
Twelve predictive models were characterized by a high determination coefficient and small RMSE (Table 3). The data obtained for samples stored at $4 \pm 1^{\circ} \mathrm{C}$ was fitted into Baranyi model and graphically very well. However, $R^{2}$ values are not recommended with non-linear regression to judge model performance as absolute indices (Ross, 1996). Thus $B_{f}$ and $A_{f}$ were recommended (Baranyi et al., 1996). For total viable cells, $B_{f}$ and $A_{f}$ values of control were 1.004 and 1.016, respectively (perfect agreement would be 1.0). The $B_{f}$ of 1.004 indicates that the predictive bacterial counts exceeded the observed counts by approximately $0.4 \%$. Therefore, the values of $B_{f}, A_{f}$, RMSE, and $R^{2}$ statistics indicated that the Baranyi model could provide accurate predictions of growth data. The statistical indices of anaerobic and psychrotrophic bacteria also showed that the Baranyi model was reliable enough to describe bacterial growth curves in our frankfurter samples. Although we made models under real foods, there are not enough data to compare the effect of dietary fiber on bacterial growth in meat products. Thus, the experiments continuously should be tried to obtain data on the effect of dietary fiber or other factors such as water activity, $\mathrm{pH}$, and water contents on the bacterial growth.

\section{Estimation of shelf-life}

The critical level of bacteria related to spoilage or foodborn disease in cooked meat products varies extensively, therefore we followed the Korean Food Standards Codex (Korean Food and Drug Administration, 2008). The Korean Food Standards Codex regulates the critical level 
Table 3. Evaluation of the predictive model against experimental data of frankfurter sausage containing dietary fiber

\begin{tabular}{clcccc}
\hline \hline \multirow{2}{*}{ Microorganism } & \multirow{2}{*}{ Type } & \multicolumn{4}{c}{ Statistical analysis } \\
\cline { 3 - 6 } & & $R^{25}$ & RMSE $^{6)}$ & $B_{f}{ }^{7)}$ & $A_{f}{ }^{8}$ \\
\hline \multirow{3}{*}{ Total viable } & $\mathrm{C}^{1)}$ & 0.999 & 0.05 & 1.004 & 1.016 \\
cells & $\mathrm{T}^{2)}$ & 0.997 & 0.08 & 1.002 & 1.021 \\
& $\mathrm{~T}^{3)}$ & 0.996 & 0.08 & 1.001 & 1.022 \\
& $\mathrm{~T}^{4)}$ & 0.997 & 0.08 & 0.999 & 1.015 \\
\hline \multirow{3}{*}{ Anaerobic } & $\mathrm{C}$ & 0.994 & 0.03 & 1.005 & 1.022 \\
bacteria & $\mathrm{T} 1$ & 0.999 & 0.07 & 1.000 & 1.042 \\
& $\mathrm{~T} 2$ & 0.961 & 0.09 & 1.027 & 1.065 \\
& $\mathrm{~T} 3$ & 0.989 & 0.16 & 1.007 & 1.099 \\
\hline \multirow{3}{*}{ Psychrotrophic } & $\mathrm{C}$ & 0.985 & 0.04 & 1.039 & 1.045 \\
bacteria & $\mathrm{T} 1$ & 0.986 & 0.11 & 1.014 & 1.045 \\
& $\mathrm{~T} 2$ & 0.989 & 0.15 & 1.029 & 1.062 \\
& $\mathrm{~T} 3$ & 0.984 & 0.12 & 1.029 & 1.062 \\
\hline
\end{tabular}

${ }^{1)}$ Control, ${ }^{2}$ frankfurter with $1 \%$ fiber added, ${ }^{3}$ frankfurter with $2 \%$ fiber added, ${ }^{4)}$ frankfurter with $3 \%$ fiber added, ${ }^{5}$ correlation coefficient, ${ }^{6}$ root mean square error, ${ }^{7}$ bias factors; ${ }^{8)}$ accuracy factors.

Table 4. Evaluation of shelf-life of frankfurter sausage containing dietary fiber under $4 \pm 1^{\circ} \mathrm{C}$ storage

\begin{tabular}{cccc}
\hline \hline \multirow{2}{*}{ Microorganism } & Type & \multicolumn{2}{c}{ Shelf-life (days) } \\
\cline { 3 - 4 } & & $\begin{array}{c}\text { Predicted } \\
\text { shelf-life }^{5}\end{array}$ & $\begin{array}{c}\text { Estimated } \\
\text { shelf-life }^{6}\end{array}$ \\
\hline \multirow{2}{*}{ Total viable } & $\mathrm{C}^{1)}$ & 11.7 & 7.8 \\
cells & $\mathrm{T}^{2)}$ & 11.8 & 7.9 \\
& $\mathrm{~T}^{3)}$ & 11.9 & 7.9 \\
& $\mathrm{~T}^{3)}$ & 11.6 & 7.7 \\
\hline
\end{tabular}

${ }^{1)}$ Control; ${ }^{2}$ frankfurter with $1 \%$ fiber added; ${ }^{3)}$ frankfurter with $2 \%$ fiber added; ${ }^{4)}$ frankfurter with $3 \%$ fiber added; ${ }^{5}$ days to reach $10^{4}$ $\mathrm{CFU} / \mathrm{g} ;{ }^{6}$ shelf-life estimated from equation (7).

of total viable cells ( $4 \mathrm{Log} \mathrm{CFU} / \mathrm{g}$ ) in cooked meat products. The shelf-life of frankfurters was assessed by measuring the time taken to reach the limit of $4 \mathrm{Log} \mathrm{CFU} / \mathrm{g}$ of total viable cells under $4 \pm 1^{\circ} \mathrm{C}$ storage for 35 days. The values obtained from control, T1, T2, and T3 were compared each other (Table 4). The predicted shelf-life was $11.7,11.8,11.9$, and 11.6 days. To calculate shelf-life more reliably, the predicted shelf-life was calculated again by considering the safety factor (1/1.5). The estimated shelf-life was 7.8, 7.9, 7.9, and 7.7 days. The shelflife of frankfurter sausages was similar between control and treatments and appeared to be independent on the contents of dietary fiber.

According to the new rule(s) established by KFDA (Korean Food and Drug Administration, Notification No. 2007-66), the food company should present the shelf-life of food products and the proof such as scientific method of shelf-life estimation, and procedures. However the reliable standard experimental methods for the estimation of shelf-life depending on various food characteristics have not been developed sufficiently. The microbiological quality in food is concerned as food spoilage and safety undoubtedly these days. And also ensuring the microbiological safety on food is critical problem for food control and distribution. The mathematical predictive models of microorganism have been developed for understanding the bacterial growth related to spoilage or food borne disease (Dalgaard, 1995; Fujikawa et al., 2004). Therefore, the application of predictive modeling may be the reliable approach for estimation of shelf-life.

\section{Acknowledgements}

This research was supported by the Rural Development Administration (\#033-006-001-01-00) and the Brain Korea 21 project in Korea.

\section{References}

1. Abdul-Hamid, A. and Luan, Y. S. (2000) Functional properties of dietary fiber prepared from defatted rice bran. Food Chem. 68, 15-19.

2. AOAC (1995) Official methods of analysis of AOAC. 16th ed. Association of official analytical chemists, Washington, DC.

3. Aranceta, J. (2003) Community nutrition. Eur. J. Clinical Nutr. 57, 79-81.

4. BAM (2003) Bacteriological Analytical Manual Online. Available from http://www.cfsan.fda.gov/ ebam. Accessed 8 January 2008.

5. Baranyi, T., Robinson, T. P., Kaloti, A., and Mackey, B. M. (1995) Predicting growth of Brochothrix thermosphacta at changing temperature. Int. J. Food Microbiol. 27, 61-75.

6. Baranyi, J., Ross, T., Roberts, T. A., and McMeekin, T. A. (1996) Effects of parameterization on the performance of empirical models used in 'predictive microbiology'. Food Microbiol. 13, 83-91.

7. Cara, L., Borel, P., Armand, M., Lafont, H., Lesgards, G., and Lairon, D. (1992) Milling and processing of wheat and other cereals affect their capacity to inhibit pancreatic lipase in vitro. J. Food Sci. 57, 466-469.

8. Chin, K. B., Kim, W. Y., and Kim, K. H. (2005) Physicochemical and textural properties and antimicrobial effects of low-fat comminuted sausages manufactured with grapefruit seed extract. Korean J. Food Sci. Ani. Resour. 25, 141-148.

9. Choi, Y. S., Jeong, J. Y., Choi, J. H., Han, D. J., Kim, H. Y., Lee, M. A., Sim, S. Y., Paik, H. D., and Kim, C. J. (2007) Quality characteristics of meat batters containing dietary fiber extracted from rice bran. Korean J. Food Sci. Ani. Resour. 27, 228-234. 
10. Dalgaard, P. (1995) Modelling of microbial activity and prediction of shelf life of packed fish. Int. J. Food Microbiol. 26, 305-318.

11. Elleuch, M., Besbes, S., Roiseux, O., Blecker, C., Deroanne, B., Drira, N., and Attia, H. (2008) Date flesh: Chemical composition and characteristics of the dietary fiber. Food Chem. 111, 676-682.

12. Fujikawa, H., Kai, A., and Morozumi, S. (2004) A new logistic model for Escherichia coli growth at constant and dynamic temperatures. Food Microbiol. 21, 501-509.

13. Koo, M. S., Kim, Y. S., Shin, D. B., Oh, S. W., and Chun, H. S. (2007) Shelf-life of prepacked kimbab and sandwiches marketed in convenience stores at refrigerated condition. $J$. Food Hyg. Safety 22, 323-331.

14. Korea Health Industry Development Institute (KHIDI) (2008) Development of guideline for establishment of shelflife of foods. The final report of Korea Food and Drug Administration research project (Project No. 2008-26) pp. 234-243.

15. Korean Food and Drug Administration (2008) Korean Food Standards Codex. pp. 73-77.

16. Korean Food and Drug Administration (2007) The criterion for shelf-life settlement of food (KFDA, Notification No. 2007-66).

17. Koutsoumanis, K. and Nychas, G. J. E. (2000) Application of a systematic experimental procedure to develop a microbial model for rapid fish shelf life predictions. Int. J. Food Microbiol. 60, 171-184.

18. Lee, H. M., Lee, G. Y., Yoon, E. Y., Kim, H. J., Kang, Y. S., Lee, D. H., Park, J. S., Lee, S. H., Woo, G. J., Kang, S. H., Yang, J. S., and Yang, K. H. (2004) Computation of maximum edible time using monitoring data of Staphylococcus aureus in Kimbap and Food MicroModel. J. Food Hyg.
Safety 19, 49-54.

19. Martin, A. R., Nieto, J. M. M., Ruiz, J. P. N., and Jimenez, L. E. (2008) Overweight and obesity: The role of education, employment and income in Spanish adults. Appetite 51, 266272.

20. Park, S. Y., Choi, J. W., Chung, D. H., Kim, M. G., Lee, K. H., Kim, K. S., Bahk, G. J., Bae, D. H., Park, S. K., Kim, K. Y., Kim, C. H., and Ha, S. D. (2007) Development of a predictive mathematical model for the growth kinetics of Listeria monocytogenes in Sesame leaves. Food Sci. Biotechnol. 16, 238-242.

21. Ross. T. (1996) Indices for performance evaluation of predictive models in food microbiology. J. Appl. Bacteriol. 81, 501-508.

22. Ross. T., Dalgaard, P., and Tienungoon, S. (2000) Predictive modeling of the growth and survival of Listeria in fishery products. Int. J. Food Microbiol. 62, 231-245.

23. SAS (1999) SAS/STAT Software. Release 8.1, SAS Institute Inc., Cary, NC, USA.

24. Wang, J., Rosell, C. M., and Barber, C. B. (2002) Effect of the addition of different fibers on wheat dough performance and bread quality. Food Chem. 79, 221-226.

25. Wilson, P. D. G., Brochlehhust, T. F., Arino, S., Thuault, D., Jakobsen, M., Lange, M., Farkas, J., Wimpenny, J. W. T., and Van Impe, J. F. (2002) Modelling microbial growth in structured foods: towards an unified approach. Int. J. Food Microbiol. 73, 275-289.

26. Wrick, K. L., Robertson, J. B., Van Soest, P. J., Lewis, B. A., Rivers, J. M., Roe, D. A., and Hackler, L. R. (1983) The influence of dietary fiber source on human intestinal transit and stool output. J. Nutr. 113, 1464-1479.

(Received 2008.8.22/Revised 1st 2008.12.9, 2nd 2009.1.10/ Accepted 2009.1.12) 